\title{
PENGARUH BUDAYA DAN IKLIM ORGANISASITERHADAP KINERJA TENAGA PARAMEDIS RUMAH SAKIT XYZ
}

\author{
Meri Sandora Alvi \\ Fakultas Ekonomi dan Sosial UIN Sultan Syarif Kasim Riau - Pekanbaru \\ E-mail: sandora.meri@yahoo.com \\ Alvi \\ Fakultas Ekonomi dan Sosial UIN Sultan Syarif Kasim Riau - Pekanbaru \\ E-mail: alvi@uin-suska.ac.id
}

\begin{abstract}
Abstrak
Penelitian ini dilakukan pada Rumah Sakit XYZ, tujuan dalam penelitian ini adalah untuk mengetahui pengaruh budaya dan iklim organisasi terhadap kinerja tenaga paramedis pada Rumah sakit XYZ. Adapun sampel dalam penelitian ini adalah tenaga paramedis yang berjumlah 81 orang yang dijadikan sebagai responden, analisis data dalam penelitian ini adalah kuantitatif dengan menggunakan metode regresi linier berganda dan pengolahan data mengunakan program SPSS 17. Berdasarkan hasil Uji Regresi Linear Berganda di peroleh persamaan: $Y=3,815+0,481 X_{1}+0,442 X_{2}$, kemudian hasil analisis uji secara parsial (uji $T$ ) variabel budaya organisasi didapatkan $T_{\text {hitung }}$ sebesar 5,126> dari $T_{\text {tabel }} 1,99$ dan variabel iklim organisasi $T_{\text {hitung }}$ sebesar $4,411>$ dari $T_{\text {tabel }} 1,99$, uji analisis secara parsial budaya organisasi dan iklim organisasi memiliki pengaruh positif terhadap kinerja tenaga paramedis pada Rumah Sakit XYZ, kemudian hasil analisis secara simultan didapatkan $F$ hitung sebesar 235,787 > $F_{\text {tabel }}$ sebesar 3,11 atau dengan signifikansi sebesar 0,000 <0,05 maka variabel budaya dan iklim organisasi diuji secara simultan memiliki pengaruh signifikan terhadap kinerja tenaga paramedis Rumah Sakit XYZ. Nilai Adjusted $R$ square 0,854 yang artinya 85,4 \% dari budaya organisasi dan iklim organisasi berpengaruh terhadap kinerja tenaga paramedis pada Rumah XYZ, sedangkan sisanya 14,6\% dipengaruhi sebab-sebab lainnya yang tidak diteliti dalam penelitian ini.
\end{abstract}

Kata kunci : Budaya Organisasi, Iklim Organisasi, Kinerja

\section{PENDAHULUAN}

Organisasi sebagai tempat atau wadah dimana orang-orang berkumpul bekerjasama secara rasional dan sistematis, terencana, terorganisasi, terpimpin dan terkendali, dalam memanfaatkan sumber daya organisasi (uang, material, mesin, metode, lingkungan, sarana-parasarana, data) secara efisien dan efektif untuk mencapai tujuan yang telah ditentukan.

Kerjasama dimaksud adalah kerjasama yang terarah pada pencapaian tujuan. Kerjasama yang terarah tersebut dilakukan dengan mengikuti pola interaksi antar setiap individu atau kelompok. Pola interaksi tersebut diselaraskan dengan berbagai aturan, norma, keyakinan, nilai-nilai tertentu 
sebagaimana ditetapkan oleh para pendiri organisasi itu. Keseluruhan pola interaksi tersebut dalam waktu tertentu akan membentuk suatu kebiasaan bersama atau membentuk budaya organisasi.

Dewasa ini, dalam rangka menyikapi tantangan perubahan zaman yang terjadi, organisasi modern dituntut untuk dapat meletakkan landasan budaya yang paling sesuai diterapkan pada seluruh lapisan organisasi, agar keefektifan sumber daya manusia dapat diperoleh sehingga dapat meningkatkan kinerja organisasi. Konsep budaya organisasi disandarkan pada kemampuan individu, sehingga penguatan yang diberikan pada manusia selaku individu sebagai sumberdaya manusia semakin disadari merupakan aset organisasi yang paling berharga dan memiliki kemampuan beradaptasi yang paling fleksibel.

Kemampuan individual sumber daya manusia tenaga paramedis dirumah sakit mutlak dicapai guna peningkatan profesionalisme, untuk menjembatani kondisi ideal yang diinginkan organisasi dengan realita yang terjadi, penerapan budaya yang sesuai beserta iklim bagi keberhasilan kinerja tenaga paramedis mutlak diperlukan. Diharapkan dengan adanya ketepatan penerapan iklim dan budaya pada berbagai situasi dan kondisi, misi dan tujuan rumah sakit dapat dicapai.

Tenaga paramedis merupakan ujung tombak dalam memberikan pelayanan perawatan bagi pasien di rumah sakit, sebagai aktor yang berhubungan langsung dengan pasien dalam waktu yang lama. Kondisi yang seperti itu menuntut totalitas seorang tenaga paramedis dalam menjalankan fungsinya, sebab dari sisi inilah pencapaian tujuan rumah sakit dapat dirasakan secara nyata.

$$
\text { Sebagaimana tercantum }
$$

dalam Garis-garis Besar Haluan Negara (GBHN), maka pembangunan kesehatan ditujukan untuk memperluas kesempatan guna mendapatkan derajat kesehatan yang sebaik-baiknya bagi setiap warga negara sejalan dengan meningkatnya usaha pembangunan. Dalam rangka ini maka pelayanan kesehatan yang lebih merata juga ditingkatkan, untuk mencapai tahap tersebut diperlukan tenaga paramedis yang kompeten, berdedikasi dengan tingkat kinerja tinggi dalam memberikan pelayanan perawatan medis bagi pasien pada Rumah Sakit.

Penulis dapat membuat rumusan permasalahan dalam penelitian ini:Bagaimana pengaruh budaya,Iklim organisasi terhadap kinerja Tenaga Paramedis Rumah Sakit baik secara simultan maupun parsial.

Adapun tujuan penelitian ini adalah Untuk mengetahui pengaruh budaya dan iklim organisasi terhadap kinerja Tenaga Paramedis Rumah Sakit baik secara simultan maupun parsial.

Penelitian ini diharapkan bisa memberikan masukan bagi pihak Rumah Sakit dalam pengembangan budaya dan iklim organisasi, Selain itu penelitian ini juga dapat digunakan sebagai bahan referensi bagi peneliti yang lain tentang pemahaman budaya dan iklim organisasi. 


\section{TINJAUAN PUSTAKA \\ Budaya}

Dalam meramalkan perilaku organisasi terlebih dahulu perlu dipahami budaya organisasi itu sendiri, menurut Jenifer dan Gareth (Tampubolon, 2004: 188) budaya organisasi adalah informalisasi dari satuan nilai dan norma sebagai alat kontrol bagi langkah-langkah karyawan dan kelompoknya di dalam organisasi untuk berinteraksi secara agresif, cepat, dan mudah dengan yang lainnya, serta dengan orang di luar organisasi sebagai pelanggan dan pemasok.

Menurut Stephen P. Robbins dalam bukunya Organizational Behavior (Tika, 2005:13) membagi lima fungsi budaya organisasi, sebagai berikut:

1. Berperan menetapkan batasan.

2. Mengantarkan suatu perasaan identitas bagi anggota organisasi.

3. Mempermudah timbulnya komitmen yang lebih luas dari pada ke pentingan individual seseorang.

4. Meningkatkan stabilitas sistem sosial karena merupakan perekat sosial yang membantu mempersatukan organisasi.

5. Sebagai mekanisme kontrol dan menjadi rasional yang memandu dan membentuk sikap serta perilaku para karyawan.

Deal \& Kenedy dalam bukunya Corporate Culture: The Roles and Ritual of Corporate (Tika, 2005:1617) membagi lima unsur pembentukan budaya:

1. Lingkungan usaha, merupakan unsur yang menentukan terhadap apa yang harus dilakukan perusahaan agar bisa berhasil.
2. Nilai-nilai, merupakan keyakinan dasar yang dianut oleh sebuah organisasi.

3. Pahlawan, merupakan tokoh yang dipandang berhasil mewujudkan nilai-nilai budaya kedalam kehidupan nyata.

4. Ritual, merupakan tempat dimana perusahaan secara simbolis menghormati pahlawanpahlawannya.

5. Jaringan budaya, jaringan komunikasi informal yang pada dasarnya merupakan saluran komunikasi primer.

\section{Jenis - Jenis Budaya Organisasi}

Pihak manajemen kini menyadari bahwa keberadaan budaya organisasi sangat penting, karena pemahaman akan norma, nilai-nilai, kebijaksanaan, dan aturan-aturan bisa menciptakan suasana kerja yang menyenangkan. Menurut Robert E. Quinn dan Michael R. Mcgrath (Tika, 2005:7) membagi budaya organisasi berdasarkan proses informasi sebagai berikut:

1. Budaya rasional

Dalam budaya ini, proses informasi individual diasumsikan sebagai sarana bagi tujuan kinerja yang ditunjukkan (efisiensi, produktivifitas, keuntungan atau dampak).

2. Budaya ideologis

Dalam budaya ini, pemrosesan informasi intuitif (dari pengetahuan yang dalam, pendapat dan inovasi) diasumsikan sebagai sarana bagi tujuan revitalisasi.

3. Budaya konsensus

Dalam budaya ini, pemrosesan informasi kolektif (diskusi, partisipasi dan konsensus) diasumsikan sebagai sarana bagi 
tujuan kohesi (iklim, moral dan kerjasama kelompok).

4. Budaya heirarkis

Dalam budaya hierarkis, pemrosesan informasi formal (dokumentasi, komputasi dan evaluasi) diasumsikan sebagai sarana bagi tujuan kesinambungan (stabilitas, control dan koordinasi).

\section{Indikator Budaya Organisasi}

Dari pengembangan jenis budaya dan karakteristik budaya organisasi, dipaparkan indikator budaya organisasi yang menjadi dasar pembentukan budaya itu sendiri. Menurut Wirawan (2007:1011) Indikator budaya organisasi dibagi menjadi :

1. Kepercayaan.

2. Norma.

3. Nilai-nilai.

4. Pola perilaku.

5. Kebiasaan organisasi.

6. Etos kerja.

7. Kode etik.

\section{Pengaruh Budaya Organisasi} Terhadap Kinerja

Menurut Victor Tan (Wibowo, 2007:383) budaya organisasi berdampak pada kinerja jangka panjang organisasi, bahkan mungkin merupakan faktor penting dalam menentukan keberhasilan atau kegagalan organisasi. Meskipun tidak mudah untuk berubah, budaya organisasi dapat meningkatkan kinerja sehingga produktifitas organisasi meningkat.

Dalam Tika (2005:177-178) studi di Indonesia yang dilakukan oleh Nurfarhaty menyimpulkan bahwa:

1. Budaya organisasi mempunyai pengaruh yang erat dengan kinerja karyawan.
2. Budaya organisasi, yang terdiri dari inovasi dan kepedulian, perilaku pimpinan dan orientasi tim, berpengaruh terhadap kinerja karyawan.

\section{Iklim Organisasi}

Iklim organisasi penting untuk diciptakan karena iklim organisasi berhubungan erat dengan persepsi individu, yaitu tentang apa yang telah diberikan oleh organisasi dan dijadikan dasar bagi penentuan tingkah laku anggota selanjutnya. Iklim organisasi ditentukan oleh seberapa baik anggota diarahkan, dibangun dan dihargai organisasi itu sendiri.

Istilah Iklim organisasi (organizational climate) pertama kali dipakai oleh Kurt Lewin pada tahun 1930-an, yang menggunakan istilah iklim psikologi (psychological climate). Kemudian istilah iklim organisasi dipakai oleh R.Tiaguri dan G. Litwin. Tiaguri mengemukakan istilah untuk melukiskan perilaku dalam hubungan dengan latar belakang atau tempat (setting) dimana perilaku muncul.

Menurut Lussier dalam Marlina (2012: 8) mengatakan bahwa iklim organisasi adalah persepsi pegawai mengenai kualitas lingkungan internal organisasi yang secara relative dirasakan anggota organisasi yang kemudian mempengaruhi perilaku mereka berikutnya.

Menurut Simamora dalam Marlina (2012: 9) bahwa iklim organisasi adalah lingkungan internal atau psikologi organisasi. Iklim organisasi mempengaruhi praktek dan kebijakan SDM yang diterima oleh anggota organisasi, perlu diketahui bahwa setiap organisasi 
akan memiliki iklim organisasi yang berbeda dengan keaneka ragaman pekerjaan yang dirancang di dalam organisasi atau sifat individu yang ada akan menggambarkan perbedaan tersebut.

Menurut Dharma (2000:44) iklim organisasi adalah lingkungan manusia di mana para pegawai organisasi melakukan pekerjaan mereka, pengertian ini dapat mengacu pada lingkungan suatu departemen, unit perusahaan yang penting seperti pabrik cabang, atau suatu organisasi secara keseluruhan. Kita tidak dapat menyentuh tetapi ia (iklim) ada, iklim dipengaruhi oleh hampir semua yang terjadi di lingkungan organisasi.

Iklim organisasi adalah persepsi anggota organisasi (secara individual dan kelompok) dan mereka yang secara tetap berhubungan dengan organisasi (misalnya pemasok, konsumen, konsultan dan kontraktor) mengenai apa yang ada atau terjadi di lingkungan internal organisasi secara rutin, yang mempengaruhi sikap dan perilaku organisasi dan kinerja anggota organisasi yang kemudian menentukan kinerja organisasi, (Wirawan,2007:122).

Dari penjelasan dari definisi di atas ada sejumlah kata kunci perlu mendapat penjelasan mengenai definisi di atas, (Wirawan,2007:122):

\section{Persepsi}

Persepsi adalah proses orang menerima, mengorganisasi dan menginterpretasikan informasi yang ada dilingkungannya dan menggunakannya untuk mengambil keputusan, melakukan aktivitas, dan sebagainya. Untuk mengetahui iklim organisasi, peneliti dapat menjaring persepsi anggota secara individual atau kelompok.

2. Praktik rutin

Persepsi anggota organisasi dalam persepsi rutin anggota organisasi mengenai apa yang terjadi secara rutin dalam organisasi. Misal: suasana organisasi menjelang hari raya dan tahun baru berbeda dengan suasana hari-hari biasa, di kantor-kantor pemerintah Indonesia fokus karyawan tersita untuk pulang mudik.

3. Sikap dan perilaku organisasi Persepsi orang mengenai lingkungan organisasi mempengaruhi sikap orang. Misalnya, orang dapat berperilaku dari sangat tidak disiplin sampai sangat disiplin. Perilaku dapat juga dalam bentuk sangat terbuka sampai perilaku sangat tertutup.

Sikap dan prilaku organisasi mempengaruhi kinerja mereka secara individual dan kelompok yang kemudian mempengaruhi kinerja organisasi. Misalnya, persepsi negatif karyawan terhadap kepemimpinan, sistem manajemen, pelaksanaan norma, serta peraturan organisasi dan pekerjaannya, mempengaruhi perilaku mereka dalam melaksanakan pekerjaannya. Perilaku ini berpengaruh terhadap produktifitas mereka yang kemudian mempengaruhi kinerja organisasi.

\section{Kinerja}

Bagi suatu organisasi, kinerja merupakan hasil dari kegiatan kerjasama diantara anggota atau komponen organisasi dalam rangka mewujudkan tujuan organisasi. Sederhananya, kinerja merupakan produk dari kegiatan admistrasi yaitu dari kegiatan kerjasama untuk 
mencapai tujuan yang pengelolaannya biasa disebut dengan manajemen.

Menurut Mangkunegara (2005: 67) mendefinisikan kinerja adalah hasil kerja secara kualitas dan kuantitas yang dicapai oleh seorang pegawai dalam melaksanakan tugasnya sesuai dengan tanggung jawab yang diberikan kepadanya.

Sedangkan menurut Wirawan (2009:5) kinerja adalah keluaran yang dihasilkan oleh fungsi-fungsi atau indikator-indikator suatu pekerjaan atau suatu profesi dalam waktu tertentu.

Pengertian kinerja telah dirumuskan oleh beberapa ahli manajemen dalam Tika (2005:121) sebagai berikut:

1. Stoner, dalam bukunya Management mengemukakan bahwa kinerja adalah fungsi motivasi, kecakapan dan persepsi peranan.

2. Bernardin dan Russel (dalam bukunya Achmad S. Ruby) mendefinisikan kinerja sebagai pencatatan hasil-hasil yang diperoleh dari fungsi-fungsi pekerjaan atau kegiatan tertentu selama kurun waktu tertentu.

3. Handoko dalam bukunya Management Personalia dan Sumber Daya mendefinisikan kinerja sebagai proses dimana organisasi mengevaluasi atau menilai prestasi kerja karyawan.

Kinerja merupakan hasil pencapaian terhadap kegiatan yang dilakukan oleh seorang karyawan atas pekerjaannya. Kinerja dikatan baik apabila seorang karyawan mampu melaksanakan pekerjaan berdasarkan prosedur yang ada dan selaras dengan tujuan organisasi.

\section{Faktor-faktor kinerja}

Menurut model partner-lawyer (Donelly, Gibson and Ivancevich) (Rivai, 2008:16), kinerjaindividu pada dasarnya dipengaruhi oleh faktor-faktor sebagai berikut:

1. Harapan mengenai imbalan.

2. Dorongan.

3. Kemampuan, kebutuhan dan sifat.

4. Persepsi terhadap tugas.

5. Imbalan internal dan eksternal.

6. Persepsi terhadap tingkat imbalan dan kepuasan kerja.

Dengan demikian, kinerja pada dasarnya ditentukan oleh tiga hal yaitu: kemampuan, keinginan, dan lingkungan (iklim organisasi).

\section{Penilaian Kinerja}

Kinerja merupakan perilaku nyata yang ditampilkan setiap orang sebagai prestasi kerja yang dihasilkan oleh karyawan sesuai dengan perannya dalam perusahaan. Salah satu cara yang dapat digunakan untuk melihat perkembangan perusahaan adalah dengan melakukan penilaian kinerja.

Menurut Rivai (2009:549) penilaian kinerja merupakan salah satu cara yang dapat digunakan untuk melihat perkembangan perusahaan adalah dengan cara melihat hasil dari penilaian kinerja. Sasaran yang menjadi objek penilaian kinerja adalah kecakapan, kemampuan karyawan dalam melaksanakan suatu pekerjaan atau tugas yang dievaluasi dengan menggunakan tolak ukur tertentu secara objektif.

\section{Elemen proses manajemen kinerja}

Manajemen kinerja adalah usaha atau kegiatan optimalisasi kinerja karyawan yang diprakarsai dan dilaksanakan oleh pimpinan 
didalam sebuah organisasi. Karena program ini dimulai dengan kata manajemen, maka program ini harus melakukan pola proses manajemen yaitu dengan menetapkan tujuan dan sasaran terlebih dahulu.

Menurut Wibisono (2006: 26) menyatakan empat tahap dalam manajemen kinerja, keempat tahap tersebut adalah sebagai berikut:

1. Tahap 0: fondasi

Pemahaman atas pedoman prinsip yang harus dijadikan fondasi bagi rancangan awal.

2. Tahap 1: perancangan

Merupakan langkah perancangan sistem manajemen kinerja yang terdiri dari visi, misi, strategi dan kerangka kerja.

3. Tahap 2: penerapan

Merupakan tahap penerapan rancangan yang meliputi display yang akan didukung, laporan yang akan dirancang, sosialisasi kepada seluruh karyawan, analisis manfaat, SDM yang akan terlibat dalam penerapan.

4. Tahap 3: penyegaran

Merupakan langkah evaluasi terhadap kemutakhiran sistem manajemen kinerja yang dirancang dengan mempertimbangkan informasi dan pengetahuan terkini.

\section{Aspek-aspek penilaian kinerja dan standar pekerjaan}

Menurut Hasibuan (2005:95) mengemukakan bahwa aspek-aspek yang dinilai dalam kinerja adalah sebagai berikut:

1. Kesetiaan

Penilaian pengukur kesetiaan karyawan terhadap pekerjaaannya, jabatannya, dan organisasi. Kesetiaan ini tercermin oleh kesediaan karyawan menjaga dan membela organisasi didalam maupun diluar dari pekerjaan orang-orang yang tidak bertanggung jawab.

2. Prestasi Kerja Penilaian prestasi kerja baik dari segi kualitas maupun kuantitas yang dapat dihasilkan karyawan tersebut dari uraian pekerjaan.

3. Kejujuran

Penilai menilai kejujuran berdasarkan tugas-tugasnya memenuhi perjanjian baik bagi dirinya maupun terhadap orang lain seperti bawahannya.

4. Kedisiplinan

Penilaian menilai disiplin karyawan dalam mematuhi peraturan-praturan yang ada dan melakukan pekerjaan sesuai dengan instruksi yang telah diberikan kepadanya.

5. Kreativitas

Penilai menilai kemampuan karyawan dalam mengembangkan kreativitasnya untuk menyelesaikan pekerjaannya, sehingga bekerja lebih berdaya guna dan berhasil guna.

6. Kerjasama

Penilai menilai kesediaan karyawan berpartisipasi dan bekerjasama dengan karyawan lainnya secara vertikal dan horizontal diluar maupun didalam pekerjaan sehingga pekerjaan akan semakin baik.

7. Kepemimpinan

Penilai menilai karyawan untuk memimpin, berpengaruh, mempunyai pribadi yang kuat, dihormati, berwibawa, dan dapat memotivasi bawahannya atau orang lain untuk bekerja secara efektif.

8. Prakarsa 
Penilai menilai kemampuan berpikir yang orisinal dan berdasarkan inisiatif sendiri untuk menganalisis, memberi alasan dan mendapatkan kesimpulan, serta membuat keputusan penyelesaian masalah yang dihadapinya.

9. Tanggung jawab dan kecakapan Penilai menilai kesediaan karyawan dalam mempertanggungjawabkan

kebijaksanaan, pekerjaan dan hasil kerjanya, sarana dan prasarana yang digunakannya, serta perilaku kerjanya.

Adapun standar dari aspekaspek pekerjaan terdiri dari kualitatif dan kuantitatif. Aspek kuantitatif meliputi:

1. Proses kerja dan kondisi pekerjaan.

2. Waktu yang dipergunakan dan lamanya penyelesaian pekerjaan.

3. Jumlah kesalahan dalam melakukan pekerjaan.

4. Jumlah dan jenis pemberian dalam bekerja.

Aspek kualitatif meliputi:

1. Kecepatan kerja dan kualitas pekerjaan.

2. Tingkat kemampuan dalam bekerja.

3. Kemampuan menganalisis data atau informasi, kemampuan atau kegagalan peralatan.

4. Kemampuan mengevaluasi (keluhan atau kebiasaan pelanggan).

Langkah-langkah dalam penilaian kinerja

Langkah-langkah penilaian

kinerja menurut Rivai (2008:27) sebagai berikut:

1. Meneliti tugas pokok dan fungsi perusahaan.
2. Meneliti tujuan kebijakan dan program-program yang ada pada perusahaan.

3. Meneliti sasaran program, sasaran pelaksanaan tugas dan targettarget yang telah ditetapkan.

4. Mambuat daftar variabel-variabel masukan dan proses.

5. Memilih indikator-indikator yang diinginkan.

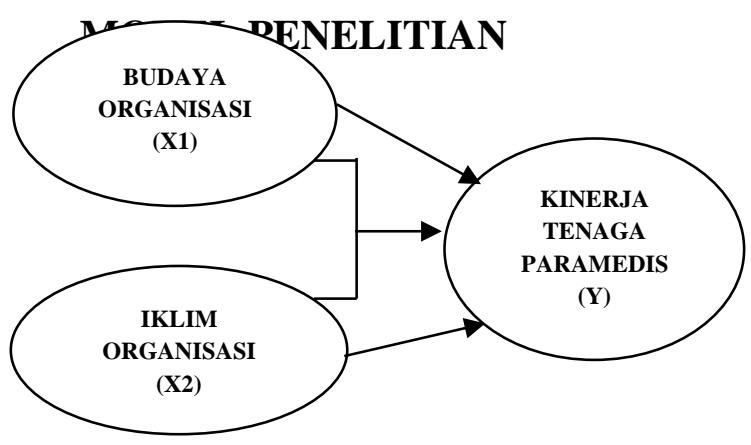

\section{PEMBAHASAN}

Tinggi rendahnya budaya organisasi dapat dilihat dari tingkat komitmen anggota rumah sakit terhadap nilai-nilai dan keyakinan dari pimpinan hingga ke semua lapisan karyawannya. Faktor nilainilai dan keyakinan dasar tersebut sangat berperan dalam membentuk etika, sikap, perilaku anggota organisasi dan membentuk cara pandang mereka terhadap masalah, baik internal maupun eksternal yang dihadapi dalam kehidupan berorganisasi.

Di beberapa rumah sakit, suatu rencana yang telah berhasil disusun oleh suatu tim khusus dan disahkan oleh pimpinan tidak berjalan mulus dalam penerapannya. Sebab hal itu terjadi karena tidak didukung oleh komitmen karyawan terhadap nilainilai dan keyakinan dasar. Untuk membangun komitmen tinggi itulah 
diperlukan dukungan suatu kultur atau budaya organisasi rumah sakit yang positif.

$$
\text { Ada empat macam fungsi }
$$
budaya organisasi yang sangat penting dalam membawa organisasi menuju sukses. Pertama, identitas organisasi (simbol dan harapan), sehingga anggota organisasi merasa bangga terhadap organisasinya dan pihak eksternal menaruh respek. Kedua, kestabilan organisasi sehingga secara internal seluruh karyawan merasa tenang dan yakin, demikian pula pihak eksternal yang berkepentingan. Ketiga alat pendorong organisasi, sehingga mampu menjadi dasar dan pendorong untuk mencapai tujuan organisasi. Keempat, komitmen organisasi sehingga mampu sebagai katalisator dalam membentuk komitmen untuk pelaksanaan berbagai ide

Dari hasil penelitian yang dilakukan pada rumah sakit XYZ, bahwa budaya organisasi berpengaruh terhadap kinerja tenaga paramedis. Hal ini dapat dilihat dari hasil kuesuioner budaya organisasi yang disebar kepada 81 orang tenaga paramedis, bahwa budaya organisasi yang dibangun pada rumah sakit XYZ tercermin pada sikap dalam melaksanakan kode etik dengan penuh kesabaran.

Budaya organisasi merupakan satuan norma atau nilai yang mana bagian nilai-nilai itu salah satunya terkandung dalam kode etik. Dalam tatanan asuhan praktik keperawatan profesional tenaga paramedis berpedoman pada Kode Etik Perawat Indonesia.

\begin{tabular}{llr} 
Budaya & \multicolumn{1}{c}{$\begin{array}{c}\text { organisasi akan } \\
\text { kokoh }\end{array}$} \\
semakin & dengan \\
menumbuhkan & semangat kerja yang
\end{tabular}

baik, kemudian akan menciptakan keyakinan bahwa kerja keras merupakan cara untuk mencapai tujuan dari rumah sakit dan anggota organisasi di dalamnya, khususnya tenaga paramedis.

Menurut Wirawan (2007:12) iklim organisasi adalah persepsi anggota organisasi (secara individual dan kelompok) dan mereka yang secara tetap berhubungan dengan organisasi (misalnya pemasok, konsumen, konsultan dan kontraktor) mengenai apa yang ada atau terjadi di lingkungan internal organisasi secara rutin, yang mempengaruhi sikap dan perilaku organisasi dan kinerja anggota organisasi yang kemudian menentukan kinerja organisasi.

Dalam analisa data didapatkanpersaman :

\section{$Y=3,815+0,481 X_{1}+0,442 X_{2}+e$}

Berdasarkan persamaan regresi di atas, maka dapat dijelaskan sebagai berikut:

1. Konstanta

sebesar

3,815menyatakan bahwa jika tidak ada budaya dan iklim organisasi, maka nilai kinerja tenaga paramedis Rumah Sakit akan tetap sebesar 3,815.

2. Koefisien regresi sebesar 0,481 menyatakan bahwa setiap penambahan 1 nilai Budaya Organisasi, maka akan meningkatkan kinerja tenaga paramedis Rumah Sakit sebesar 0,481 dengan asumsi besarnya variabel dependen lainnya adalah tetap.

3. Koefisien regresi sebesar 0,442 menyatakan bahwa setiap penambahan 1 nilai iklim organisasi, maka akan meningkatkan kinerja tenaga 
paramedis pada Rumah Sakit sebesar 0,442 dengan asumsi besarnya variabel dependen lainnya adalah tetap.

Hasil pengujian hipotesis menunjukkan bahwa nilai $\mathrm{F}$ hitungsebesar 235,787 $>\mathrm{F}_{\text {tabel }}$ sebesar 3,11 atau dengan nilai signifikan sebesar $0,000<0,05$ maka hipotesis diterima. Model regresi menunjukkan bahwa variabel yang terdiri dari Budaya organisasi dan Iklim organisasi secara simultan berpengaruh signifikan terhadapkinerja paramedis pada Rumah SakitXYZ Pekanbaru.

Kemudian hasil analisis uji secara parsial (uji T) variabel budaya organisasi didapatkan $\mathrm{T}$ hitung sebesar 5,126> dari $\mathrm{T}$ tabel 1,99 dan variabel iklim organisasi $\mathrm{T}_{\text {hitung sebesar } 4,411}$ $>$ dari $\mathrm{T}$ tabel 1,99 , uji analisis secara parsial budaya organisasi dan iklim organisasi memiliki pengaruh positif terhadap kinerja tenaga paramedis pada Rumah Sakit XYZ. Berdasarkan pengolahan data diketahui bahwa nilai Korelasi (R) yang dihasilkan adalah sebesar 0,926 , berarti hubungan keeratan secara bersama-sama antara variabel dependen dan variabel independen sangat kuat karena karena $\mathrm{R}$ berada diantara 0,80-1,000.

Nilai Adjusted R Square sebesar 0,854 yang artinya 85,4\% dari variabel budaya organisasi dan iklim organisasi yang mempengaruhi kinerja tenaga paramedis pada Rumah Sakit XYZ, sedangkan sisanya $\quad(100 \%-85.4 \%=14.6 \%)$ dipengaruhi sebab-sebab lain yang tidak diteliti dalam penelitian ini.

Dari hasil penelitian di atas membuktikan bahwa budaya dan iklim organisasi berpengaruh terhadap kinerja tenaga paramedis rumah sakit XYZ, maka hasil penelitian ini mendukung teori yang telah diungkapkan oleh Wirawan dan Victor Tan seperti yang telah dikutip dibawah ini:

Menurut pandangan Victor Tan (Wibowo, 2007:379) budaya organisasi merupakan satuan norma yang terdiri dari keyakinan, sikap, core values, dan pola perilaku yang dilakukan orang dalam organisasi. Keyakinan bersama, core values dan pola perilaku mempengaruhi kinerja.

Dari hasil penelitian yang dilakukan pada rumah sakit XYZ, bahwa iklim organisasi berpengaruh terhadap kinerja tenaga paramedis. Hal ini dapat dilihat dari hasil kuesioner iklim organisasi yang disebar kepada 81 responden tenaga para medis rumah sakit XYZ.

Iklim organisasi merupakan persepsi anggota oragnisasi terhadap lingkungan sekitarnya, untuk rumah sakit XYZ iklim organisasi yang dibangun oleh pihak manajemen terlihat pada penjabaran uraian pekerjaan masing-masing anggota organisasi baik itu tenaga paramedis yang telah terstruktur, sehingga tenaga paramedis memahami apa yang seharusnya mereka lakukan.

Iklim organisasi yang bagus dibangun pihak rumah sakit dengan menerapkan sistem imbalan yang sesuai dengan kinerja setiap anggotanya termasuk tenaga paramedis. Hal ini dianggap postif karena bisa mendorong mereka bekerja secara profesional, akuntabel, untuk memenuhi kriteria penilaian kinerja yang tinggi.

Untuk mencapai kinerja yang tinggi dapat dicapai dengan pelaksanaan setiap pekerjaan sesuai 
dengan standar operasional kerja yang telah ditetapkan dan disesuaikan oleh pihak manajemen rumah sakit. Salah satunya dengan menunjukkan mutu melalui dokumentasi pelaksanaan keperawatan sebagai tanggungjawab, tanggung gugat dan etik.

Dari uraian kesimpulan di atas tergambar bahwa budaya dan iklim organisasi yang dibangun pada rumah sakit XYZ sangat kuat. Jadi, dapat disimpulkan bahwa semakin kuat budaya dan iklim organisasi maka semakin tinggi tingkat kinerja anggota organisasi secara menyeluruh.

\section{DAFTAR PUSTAKA}

Dharma , Agus. 2000, "Perilaku Manusia Dalam Bekerja", PT.Gelora Aksara, Jakarta.

Hasibuan, Malayu. SP. 2005, "Manajemen Sumber Daya Manusia”, PT.Bumi Aksara, Jakarta.

Kuncoro, Mudrajad. 2009, "Metode Riset Untuk Bisnis dan Ekonomi”, Erlangga, Jakarta.

Mangkunegara, Anwar, Prabu. 2005,

"Manajemen Sumber Daya Manusia Perusahaan", PT.Remaja Rosda Karya, Bandung.

Nasution. S, 2003, "Metode Research Penelitian Ilmiah", PT.Bumi Aksara, Jakarta.

Ndraha, Taliziduhu. 2002, "Pengantar Teori Pengembangan Sumber Daya Manusia”, Penerbit Rineka Cipta, Jakarta.

Rivai, Veithzal. 2008, "Performance Appraisal", PT.Raja Grafindo, Jakarta.
2009 "Manajemen Sumber Daya Manusia untuk Perusahaan", Rajawali Pers, Jakarta.

Robbins, Stephen, P, 2002, "Perilaku Organisasi: jilid 2", PT.Prenhallindo, Jakarta.

Siagian, Sondang. P. 2003, "Manajemen Stratejik", PT.Bumi Aksara, Jakarta.

Suarli.S-Bahtiar, Yanyan. 2008,"Manajemen

Keperawatan dengan

Pendekatan

Praktis",PT.Gelora Aksara Pratama.Jakarta.

Siswanto Bedjo, 2005. "Pengantar Manajemen", PT. Bumi Aksara, Jakarta.

Sugiono. 2005, "Methode Penelitian Bisnis", CV. Alfabeta, Bnadung.

Suliyanto. 2006, "Methode Riset Bisnis", CV.Andi Offset, Yogyakarta. , 2005, "Analisis Data Dalam Aplikasi Pemasaran”, Gahlia Indonesia, Bogor.

Sumijatun. 2011, "Membudayakan Etika dalam Praktik Kpeprawatan", Salemba Medika,Jakarta.

Tampubolon, Manahan, P. 2004,"Perilaku

Keorganisasian

(Organization Behavior)", Gahlia Indonesia. Jakarta.

Tika, Mohammad. Pabundu, 2005, "Budaya Organisasi dan Peningkatan Kinerja Perusahaan", Cetakan Pertama, PT. Bhumi Aksara, Jakarta.

Tim Departemen Kesehatan RI, 2008, "Sistem Pelayanan Keperawatan", Persatuan Perawat Indonesia, Jakarta. 
Wibisono, Dermawan. 2006.

"Manajemen Kinerja;

Konsep, Desain, dan teknik

Meningkatkan Daya Saing

Perusahaan”, Erlangga.

Jakarta.

Wibowo. 2007, "Manajemen

Perubahan", PT.Raja

Grafindo Persada, Jakarta. 